\title{
Correction to: Orthodontists' knowledge and experience on referring orthognathic surgery patients to psychological support
}

Hatice Kübra Olkun'

Published online: 7 June 2021

c) Springer Medizin Verlag GmbH, ein Teil von Springer Nature 2021 Erratum zu: Wissen und Erfahrung von Kieferorthopäden bei der Vermittlung von
kieferorthopädisch-chirurgischen Patienten an eine psychologische Mitbetreuung

\section{Correction to:}

J Orofac Orthop 2021

https://doi.org/10.1007/s00056-021-00289-z

The statement below from the conclusions section in the original manuscript:

Both clinicians and patients stated that it would be beneficial to obtain training in this field.

should be:

It would be beneficial to offer clinicians training in this field.

The original article has been corrected.

Publisher's note Springer Nature remains neutral with regard to jurisdictional claims in published maps and institutional affiliations.

The online version of the original article can be found under https://doi.org/10.1007/s00056-021-00289-z.

Dr. Hatice Kübra Olkun, DDS

kubra00olkun@hotmail.com

1 Department of Orthodontics, Gülbahar, University of İstanbul, Okan, Oya Sk. 23/A, 34394 Şişli, İstanbul, Turkey 